\title{
Militārā drošība
}

\author{
RUTA CEPLE, VALDIS OTZULIS
}

Raksta mērḳis ir identificēt tos militārās drošības sektora draudu veidus, kurus Latvijas iedzīvotāji uzskata par aktuālākajiem, un tādus mainīgos lielumus kā ārējais apdraudējums, Nacionālie bruṇotie spēki un sabiedroto spēku klātbūtne.

Veiktā analīze ḷauj secināt, ka, iedzīvotāju ieskatā, ārējais apdraudējums pastāv un ka vairums aptaujāto uzskata Krieviju par galveno draudu, un tikai atsevišķos gadījumos sabiedroto spēku klātbūtne (NATO) būtu atzīstama par apdraudējumu. Arī Nacionālo bruṇoto spēku veidotās infrastruktūras tuvums daḷai iedzīvotāju raisa nedrošîbas sajūtu, galvenokārt tādēḷ, ka pastāv potenciāli Krievijas uzbrukuma draudi šiem objektiem. Kopumā iedzīvotājiem militārā drošība nav prioritāra, svarīgākie draudu veidi, viṇuprāt, ir labklājības un ekonomiskā sektora draudi.

No pašvaldỉbas darbinieku viedokḷa galvenais nedrošības avots ir Krievija, savukārt sabiedroto spēku klātbūtne ir drošību veicinošs faktors. Analizējot pašvaldību veidotos civilās aizsardzības plānus, tikai vienā pašvaldībā bija iezīmēta vispārēja rīcība militāras krīzes gadījumā, un tas liek secināt, ka pašvaldības nav gatavas šādas krīzes pārvarēšanai un paḷaujas uz valdības rīcību.

Atslēgvārdi: militārā drošiba, subjektīvā drošības uztvere, draudi, ārējais apdraudējums, sabiedroto spēku klātbūtne.

The goal of this study is to identify and characterise military threats in the defence domain. The study focuses on the threats that have been identified by the Latvian population as important and significant within such changing environments as external threats to the State, the National Armed Forces, and the Allied presence in Latvia. Based on the data collected in interviews with people in the focus groups and in-depth interviews with representatives in local government, conclusions can be drawn that the majority consider Russia to be the main threat and single source of external threat to Latvia. Only on rare occasions do people consider the deployment of NATO 
forces and the Allied presence in Latvia to be a threat. The expanding infrastructure and regional presence of the Latvian National Armed Forces (NAF) is a source for insecurity in some people, which is based on the opinion that NAF infrastructure could be a target of a military offensive by Russia. In general, military security is not the leading security threat as perceived by the people of Latvia. The priorities are welfare and economic security. Therefore, the State's defence policy is communicated successfully, and military threats are addressed; consequently, the population is not worried about military threats in general, but non-military threats prevail in the population's individual threat perception.

Russia is the cause for the main insecurity, but NATO presence enhances the sense of security in the opinion of local government representatives. The Civil Emergency Plans in various local counties were analysed. Only one county's Emergency Plan includes a real plan for action in case of military conflict or crisis. All other local governments and municipalities were unprepared for a military crisis and relied on action plans issued by the central government.

Keywords: military security, subjective security, threats, external threat, Allied presence.

\section{levads}

Militārā drošība, kas ir nacionālās drošỉbas viens no būtiskākajiem elementiem, nozīmē valsts spēju aizsargāt tās iedzīvotājus un nacionālās intereses, kā arī spēju atturēt no ārējiem draudiem. Tradicionāli militārā drošība asocièjas ar starpvalstu attiecībām, taču tā ietver arī indivīda personīgo drošību nacionāla, reg̣ionāla un starptautiska apdraudējuma apstākḷos. Militārā drošība kḷūst aktuāla apstākḷıs, kad notiek pārmaiņas starptautiskajā drošības vidē un aktualizējas sabiedroto un starptautisko organizāciju atbalsts. NATO loma šādu apdraudējumu mazināšanā savienojumā ar nacionāla līmeņa bruņoto spēku attīstību un sabiedrības iesaisti valsts aizsardzībā kḷūst izškiriroša. Līdz ar izmaiņām starptautiskajā drošỉbas vidē, ko radījusi Krievijas revizionistiskā politika pret Ukrainu, militārie draudi tiešā veidā ietekmē arī Baltijas valstis kopumā un katru no tām individuāli. Krievijas radītais apdraudējums Latvijai ir veicinājis finansējuma pieaugumu aizsardzībai, sabiedroto spēku klātbūtni un Nacionālo bruṇoto spēku (turpmāk - NBS) militāro spēju attīstību, lai nodrošinātu pietiekamu Krievijas atturēšanu. Tāpat tas ir veicinājis sabiedrībā diskusiju par ciešāku sadarbību starp NBS un iedzīvotājiem visaptverošā valsts aizsardzībā un valsts aizsardzības mācības ieviešanu skolās.

Militārā drošība Latvijas nacionālās drošības kontekstā ir bijusi klātesoša kā politiskajā, tā arī akadēmiskajā diskusijā kopš Latvijas neatkarības 
atjaunošanas 1991. gadā. Tomēr, ņemot vērā militārās drošības aktualitāti, ir bijuši vien atsevišḳi kvalitatīvi pētijumi par Latvijas iedzīvotāju militārās drošības uztveri, kas sniedz ieskatu par to, kā iedzīvotāji dažādās kopienās uztver iespējamo militāro apdraudējumu un kā veidojas sadarbība ar pašvaldībām. Tādēḷ nodaļas mērḳis ir identificēt tos militārās drošỉbas sektora draudu veidus, kurus Latvijas iedzīvotāji uzskata par aktuālākajiem. Nodaļas sākumā tiks apskatīti līdz šim veiktie pētījumi par militāro drošības sektoru Latvijā, kam sekos drošības sektora definējums, veidojot šì pētijuma teorētisko ietvaru. Pēc tam tiks izklāstīti pētijuma rezultāti un apkopoti būtiskākie secinājumi.

\section{Kas paveikts militārās drošības izpētē?}

N̦emot vērā vēsturisko pieredzi un Latvijas geeogrāfisko novietojumu, militārā drošība ir bijis viens no aktuālākajiem jautājumiem pētniecībā. Lai gan pētỉjumos militārā drošỉba netiek skaidri definēta, tā tiek saprasta kā nacionālā drošiba (national security) vai drošỉba (security) kopumā, kuras ietvaros tiek atsevišķi skatīta militārā sadaļa. Pirmie akadēmiskie darbi par Latvijas militāro drošību tiek publicēti līdz ar Latvijas Ārpolitikas institūta dibināšanu, pievēršoties Latvijas aktuālajām drošības problēmām tūlīt pēc neatkarības atgūšanas. ${ }^{1}$

Militārās drošības pētniecỉbu Latvijā var iedalìt vairākos posmos, un pirmais posms iezīmē periodu no neatkarības atgūšanas līdz brīdim, kad Latvija iestājās NATO. Šajā posmā būtiskākās akadēmiskās diskusijas ir par militārās

1 Grāmatā "Baltijas valstis: drošibas meklējumi” (Lejiņš, A., Bleiere, D. (eds.) (1996). The Baltic States: search for security. Riga: Latvian Institute of International Affairs, pp. 31-34) tiek apskatīts drošības koncepts un tā veidošanās Baltijas valstīs. Tajā tiek norādīts, ka Latvijā pēc neatkarības atgūšanas bija citāds uzskats par drošības konceptu nekā tolaik Rietumos pastāvošais. Šì drošỉbas koncepta citādā izpratne tiek skaidrota ar to, ka visi ar aizsardzību saistītie jautājumi tika risināti Maskavā, tādējādi neveicinot Latvijas akadēmiskajā vidē izpratni par to, kas ir drošỉba. Tāpat tiek pausts, ka Latvijas politiskās aprindās ar drošibu bieži vien saprata tikai un vienīgi militāro drošỉbu, kas ietvēra tādus terminus kā aizsardzība, aizsardzības koncepcija, bruṇotie spēki vai militārie draudi. 1998. gadā Latvijas Ārpolitikas institūts publicēja Roberta Dalsjē (Roberts Dalsjö) rakstu "Vai Baltijas valstis sevi spēj aizsargāt? Par pašaizsardzības spēju kvalitāti un perspektīvām”, kur viņš asi kritizē Latvijas pētniekus par to, ka militārajai drošỉbai gan akadēmiskajās, gan arī politiskajās aprindās netiek pievērsta pietiekami liela uzmanība. Šì situācija tiek raksturota kā intereses trūkums pret drošības aizsardzības jautājumiem (Dalsjö, R. (1998). Vai Baltijas valstis sevi spēj aizsargāt? Par pašaizsardzības spēju kvalitāti un perspektīvām. Rīga: Latvijas Ārpolitikas institūts, 14.-15. lpp.). Grāmatā Small States in a Turbulent environment: the Baltic perspective tiek uzsvērts, ka Baltijas valstis, tuvojoties modernākai uztverei par drošības konceptu savā dienaskārtībā, arvien biežāk iekḷauj tādus aspektus kā sociālā un individuālā drošỉba, un norādīts, ka kompromisus par nepieciešamajiem mēriem ir vieglāk panākt sabiedrības drošības sektorā nekā militārās drošibas sektorā (Lejiņš, A., Ozoliṇa, Ž. (1997). Small States in a Turbulent Environment: The Baltic perspective. Riga: Latvian Institute of International Affairs, p. 137). 
drošības jēdziena izpratni un tā lietojumu kā šaurākā (Nacionālie bruņotie spēki, militārās spējas, militārie draudi), tā arī plašākā kontekstā, runājot par jauno drošîbas arhitektūru Baltijas valstīs, Ziemel̦eiropas reǵionā un NATO kopumā. 1999. gadā Latvijas Ārpolitikas institūta organizētajā konferencē par Baltijas valstu drošỉbas aspektiem tiek norādīts, ka Latvijas militārā drošība var tikt garantēta tikai ar pilnasinīgu dalību NATO. Papildus dalībai kolektīvajā drošības sistēmā tiek uzsvērti arī tie militārās drošības elementi, kuri būtiski ietekmē Latvijas drošību, kā, piemēram, ārējie draudi (Krievijas faktors), militārās spējas, finansējums aizsardzībai un sabiedrības izpratne par drošības jautājumiem. ${ }^{2}$

Militārās drošības otrais posms sākās pēc iestāšanās Eiropas Savienībā un NATO un turpinājās līdz Ukrainas krīzei 2014. gadā. Šì posma raksturīgākās iezīmes ir diskusijas par starptautiskās drošības aktualitātēm, kuru centrā tiek izvirzīta Latvijas militārā drošība Eiropas Savienības un NATO kontekstā. Tā, piemēram, rakstu krājumā "Latvijas ārpolitika un "robežu paplašināšana"” tiek secināts, ka nacionālā drošîbas politika vairs nevar tikt atrauta no plašāka reǵionāla un starptautiska drošības konteksta. ${ }^{3}$ Turklāt pati svarīgākā pārmaiņu izpausme ir tā, ka dalība ES un NATO Latvijai piedāvā papildu instrumentus nacionālās drošības stiprināšanai. ${ }^{4}$ Papildus empīriskajiem pētỉjumiem tiek veiktas arī kvantitatīvās aptaujas, lai noskaidrotu, kāda ir iedzīvotāju attieksme pret valsts dalību NATO. Lai gan iedzīvotāju viedoklis ir mainīgs, pētījumu aǵentūras "Latvijas Fakti" veiktajās aptaujās tiek secināts, ka iedzīvotājiem ir bažas par potenciālajām izmaksām, kas Latvijai kā dalībvalstij jāmaksā par dalību NATO, tajā pašā laikā kopumā viṇi atbalsta dalỉbu šajā organizācijā. ${ }^{5}$

Savukārt trešais posms iezīmē akadēmiskās diskusijas par Latvijas militāro drošỉbu pēc Ukrainas krīzes. Tā, piemēram, Toms Rostoks un Nora Vanaga, diskutējot par Latvijas drošības aspektiem, norāda, ka Ukrainas krīze ir mainijusi militārās drošības uztveri Latvijā, to argumentējot ar trijām pazīmēm, kas saistītas ar Krievijas maigās varas izpausmēm, - NATO spēku klātbūtne Latvijā, militāro spēju attīstība un iekšējā drošība. ${ }^{6}$ Turklāt viņi norāda, ka debatēs par militāro drošību netiek apskatīts jautājums par obligāto militāro dienestu Latvijā, to pamatojot ar Lietuvas un Igaunijas piemēru, kur abās valstīs

2 Apinis, P., Lejiņš, A. (red.) (1999). How Secure Are the Baltic States? Conference Proceedings (Cik drošas ir Baltijas valstis? Konferences materiāli). Rīga: Konrad Adenauer Stiftung, Latvian Institute of International Affairs, pp. 12-13.

3 Ozoliņa, Ž. (zin. red.) (2006). Latvijas ārpolitika un “robežu paplašināšana”. Rīga: Zinātne, 32. lpp. Turpat.

5 Latvijas Fakti (2007. marts). Sabiedriskās domas aptauja par Latvijas dalību NATO, 4. lpp.

6 Rostoks, T., Vanaga, N. (2016). Latvia's security defence post-2014. Journal on Baltic Security, 2(2), pp. 71-109. 
obligātais militārais dienests ir saglabāts. Tāpat arī, pievēršoties sabiedrības izpratnes noskaidrošanai par drošības jautājumiem, Rostoks un Vanaga secina, ka militārās drošības jautājumos, kas skar Krieviju un NATO, pastāv atškirīibas starp latviešu valodā un krievu valodā runājošo respondentu viedokḷiem, t. i., latvieši biežāk nosoda Krievijas politiku un uzskata, ka jāstiprina nacionālās aizsardzības spējas un jāpanāk aizsardzības budžeta pieaugums.?

Žaneta Ozoliņa un Valdis Otzulis, diskutējot par Baltijas valstu drošības stratēgiijām, pievēršas uzn̦emošās valsts atbalstam un secina, ka Latvijas militārās drošības pamatā ir pašaizsardzības spēju attīstība un spēja uzṇemt sabiedroto spēkus. ${ }^{8}$ 2020. gadā publicētajā pētỉjumā par Latvijas sabiedrības gribu aizstāvēt valsti U. Zupa un I. Bērziṇa secina, ka visaptverošas valsts aizsardzības koncepts ietver ne tikai militārus risinājumus, bet arī nemilitārus valsts aizsardzības pasākumus. Pētijuma laikā tika aptaujāti iedzīvotāji un izkristalizējās atziņa, ka grupās, kurās respondenti ir gatavi aizstāvēt valsti, ir lielāka uzticēšanās valsts un pašvaldību institūcijām, bet mazākumtautību iedzīvotājiem ir izteiktāka atsvešinātība no militārās drošības jautājumiem, proti, viņi mazāk uzticas NBS un Zemessardzei. ${ }^{9}$

Militārās drošības jautājumi ir tikuši pētīti arī dažādās sabiedriskās domas aptaujās. Pētījumu centrs SKDS kopš 2014. gada pēc Aizsardzības ministrijas pasūtijuma regulāri veic sabiedrības aptauju par NBS tēlu, uzticēšanos tiem un NBS attīstības jautājumiem. Tā, piemēram, 2014. gadā veiktās aptaujas kvantitatīvie dati liecināja, ka 64\% iedzivotāju paļaujas uz NBS un to îstenotajiem pasākumiem drošības stiprināšanā, ${ }^{10} 2015$. gadā tie bija $60 \%,{ }^{11}$ bet, saskaņā ar Eirobarometra aptaujām par sabiedrības viedokli, 2016. gadā NBS uzticējās 70\% iedzīvotāju, ${ }^{12} 2017$. gadā $-66 \%,{ }^{13} 2018$. gadā $-66 \%,{ }^{14} 2019$. gadā $69 \%$ iedzìvotāju ${ }^{15}$.

7 Rostoks, T., Vanaga, N. (2016). Latvia's security defence post-2014. Journal on Baltic Security, 2(2), p. 101.

8 Ozolin̦a, Ž., Otzulis. V. (2016). Shaping Baltic States defence strategies: host nation support. Lithuanian Annual Strategic Review, 2016-2017, Vol. 15, p. 98.

9 Bērzin̦a, I., Zupa, U. (2020). Latvijas sabiedrības griba aizstāvēt valsti: veicinošie un kavējošie faktori. Rīga: Drošỉbas un stratēǵiskās pētniecības centrs, 28. lpp.

10 SKDS (2014. gada novembris). Latvijas iedzīvotāju viedoklis par valsts aizsardzības jautājumiem, 23. lpp. Pieejams: https://www.mod.gov.lv/lv/dokumenti

11 Turpat, 2015. gada novembris, 24. lpp.

12 European Commission (2016). Public opinion in the European Union. Standard Eurobarometer 86, Autumn 2016, p. 52.

13 Ibid., Standard Eurobarometer 88, Autumn 2017, p. 53.

14 Ibid., Standard Eurobarometer 90, Autumn 2018, p. T39.

15 Ibid., Standard Eurobarometer 92, Autumn 2019. Pieejams: T39https://ec.europa.eu/commfrontoffice/ publicopinionmobile/index.cfm/Chart/getChart/themeKy/18/groupKy/82 [skatits 20.04.2020.] 
Saskaņā ar SKDS veikto aptauju 41\% iedzīvotāju 2016. gadā norādījuši, ka drošības situācija Latvijā ir uzlabojusies, pateicoties dalībai NATO un aktīvai divpusējai sadarbībai ar citām valstīm, piemēram, ASV.$^{16}$ Taču tikai $26 \%$ aptaujāto iedzīvotāju uzskatījuši, ka NATO situāciju ir pasliktinājusi un ka tā nedarbojas kā drošîbas garants. ${ }^{17}$ 2019. gadā SKDS veiktās aptaujas dati par militāro drošību Latvijā nav publiski pieejami, tāpēc jaunākās tendences iedzīvotāju militārās drošības uztverē nav iespējams izzināt un salīdzināt.

\section{Militārās drošības jēdziens}

Militārā drošība tiek definēta kā valsts spēja sevi aizsargāt, pieņemot politiskus lēmumus un izmantojot militāru spēku. ${ }^{18}$ Polijas Nacionālās aizsardzības universitātes profesors Rišards Špira (Ryszard Szpyra) militāro drošību definē kā procesu, kura laikā norisinās nepārtrauktas izmaiṇas militārajā sfērā un kopējā valsts politiskajā vidēe. ${ }^{19}$

Viņš min šādas raksturīgas pazīmes: militāro drošību veido tādi divi galveni elementi kā valsts un tās starptautiskās vides ietvars, kas ir saistīts ar bruņoto spēku esamību. Šajā ietvarā militārais spēks ir viens no galvenajiem valsts instrumentiem, lai mazinātu potenciālo apdraudējumu. ${ }^{20}$

Buzans, Vēvers un de Vilde uzskata, ${ }^{21}$ ka militārajā sektorā valsts ir noteicošais, taču ne vienīgais elements, kam pieder militārie resursi. Būtiska loma ir politiskajai elitei, kurai ir dotas leǵitīmas tiesības izmantot militāro spēku kā iekšēju krīžu, tā arī ārēju interešu aizstāvībai. ${ }^{22}$ Militārais sektors un tā dienaskārtība ir atkarīga no valdības noturības gan pret iekšējiem, gan arī pret ārējiem draudiem, taču tas nozīmē ne tikai militārus, bet arī nemilitārus risinājumus, piemēram, migrantu krīzes, dabas katastrofas un citos gadījumos. ${ }^{23}$

16 SKDS (2016. gada novembris). Latvijas iedzīvotāju viedoklis par valsts aizsardzības jautājumiem: Latvijas iedzīvotāju aptauja, 12. lpp. Pieejams: https://www.mod.gov.lv/sites/mod/files/document/ SKDS_aptauja_2016\%20\%281\%29.pdf.

17 Turpat, 16. lpp.

18 Militārās drošỉbas definīcija. Pieejams: https://www.yourdictionary.com/military-security [skatīts 31.08.2020.]

19 Szpyra, R. (2014). Military Security within the Framework of Security Studies: Research Results. Partnership for Peace Consortium of Defense Academies and Security Studies Institutes, 13(3), p. 65.

20 Ibid., p. 66.

21 Grāmatā Security: a new framework for analysis (p. 70) tiek secināts, ka valsts teritoriālā integritāte ir tradicionāls militārās drošības mērḳis, kur reǵionālā un iekšējā drošības vide ir galvenā šī sektora problēma.

22 Buzan, B., Wæver, O., de Wilde J. Security: a new framework for analysis. London: Lynne Rienner Publisher, p. 49.

23 Ibid., p. 50. 
Kā vienu no militārās drošìbas galvenajiem elementiem Buzans, Vēvers un de Vilde min valsts militārās spējas, kas papildināmas ar tādiem mainīgajiem kā geogrāfiskais novietojums, vēsturiskā pieredze un politiskie lēmumi. ${ }^{24}$

Zoltāns Senešs (Zoltán Szenes), raksturojot militāro drošību 21. gadsimtā iepretim jaunajiem draudiem, uzskata, ka aizsardzības stratēgijas, militārā politika un bruṇoto spēku attīstîba ir jābalsta uz tādiem faktoriem kā ārējās un iekšējas drošības attiecības, jāspēj noteikt, kas tiek apdraudēts (tā ir valsts vai kāda sociālā grupa), jābūt spēkam, kas spēj sniegt drošību (bruņotie spēki, policija, drošības dienesti), un jāapzinās valsts vājie punkti. ${ }^{25}$ Senešs uzskata, ka šie faktori ir būtiski, jo 21. gadsimta mainīgā drošības vide ir veicinājusi nemitīgas izmaiņas militārās drošības sektorā, kur starpvalstu kari tās klasiskā izpratnē ir papildināti ar terorisma draudiem, kā arī konflikta eskalāciju, kam grūti noteikt robežas. ${ }^{26}$

Pamatojoties uz akadēmiskajā literatūra paustajiem viedokḷiem par militāro drošību, ir iespējams izšķirt šādus ar militāro sektoru saistìtus elementus: ārējais apdraudējums, militāro spēju attīstība jeb nacionālie bruṇotie spēki. Papildus tam arī tādus faktorus kā aizsardzības budžets, sabiedrības iesaiste valsts aizsardzībā (visaptveroša valsts aizsardzība), sabiedroto spēku klātbūtne (NATO), kas pastiprina iepriekš minēto elementu spēju nodrošināt valsts militāro drošību. Tie veido šīs nodaļas analīitisko rāmi, kurš izmantots, lai pētītu, kā sabiedrība uztver Latvijas militārās drošības sektoru.

Identificētie elementi ir integrēti fokusa grupu interviju jautājumos par iedzīvotāju subjektīvo drošību, lai izzinātu, kas militārajā sektorā ir vislielākais apdraudējums, ko izjūt noteiktas indivīdu grupas un identificē pašvaldỉbu darbinieki.

\section{Latvijas iedzīvotāji par militāro drošību}

Fokusa grupu interviju rezultātus var sadalīt vairākās tematiskās grupās atbilstoši šajā apakšnodạ̣ā definētajam zinātniskajam ietvaram par militāro drošìbu - ārējais apdraudējums, sabiedroto spēku klātbūtne (ietverot arī NATO kā drošības garantu) un NBS (ietverot aizsardzības finansējumu, spēju attīstību, visaptverošu valsts aizsardzību).

24 Buzan, B., Wæver, O., de Wilde, J. Security: a new framework for analysis. London: Lynne Rienner Publisher, p. 59.

25 Szenes, Z. (2018). Military Security Today. New Threats, New Wars, New Theories. In: Finszter, G., Sabjanics, I. (Eds.) Security Challenges in the $21^{\text {st }}$ Century. NUPS, Dialog Campus, p. 72.

26 Ibid., p. 99. 


\section{Ārējais apdraudējums}

Interviju izvērtējuma rezultātā ir iespējams secināt, ka Krieviju kā ārējo draudu Latvijas iedzīvotāji uztver neviennozīmīgi. Lai gan Latvijas geogrāfiskajam novietojumam un Krievijai kā kaimiṇvalstij ir būtiska nozīme militārās drošības uztverē, tomēr viena daļa iedzīvotāju uzskata, ka Krievija rada nenozīmīgus draudus vai nerada tos vispār, turpretī otra daļa Krieviju dēvē par galveno ārējo apdraudējumu. Kopumā Krievija kā ārējais drauds prevalē pār tādiem ārējiem draudu veidiem kā starptautiskais terorisms vai uzbrukumi kibertelpā.

Ārējā apdraudējuma uztveres dažādību vislabāk atspoguḷo Âdažu un Liepājas pašvaldību iedzīvotāji, kuru teritorijās ir izvietota ievērojama militārā infrastruktūra. Tā, piemēram, Ādažu iedzīvotāju ieskatā, Krievija ir galvenais drauds, jo NBS militārās bāzes ir izvietotas viṇu pašvaldības teritorijā.

Pensionārs, Ādažu iedzìvotājs: L̦oti liels apdraudējums. Ja runā par raķešu uzbrukumu, tad tas ir viens no mērkiem, turklāt, ja netrāpa, tad Ādaži ir apdraudēti. ${ }^{27}$

Lai gan militārās bāzes klātesamība rada ārējus draudus, tomēr iedzīvotāji ir gatavi samierināties ar to, ja šie draudi tiek kompensēti ar finansiālajiem ieguvumiem, ko sniedz militārās infrastruktūras un sabiedroto spēku klātbūtne.

Sieviete darbspējas vecumā, Ādaži: .. armijas bāzes attīstība silda pašvaldības budžetu un tās ekonomiku. ${ }^{28}$

Pretēji domā iedzīvotāji Liepājā, kur arī ir militārā bāze. Viṇi nav tik kategoriski, taču uzskata, ka Krievija ir Latvijas apdraudējums, bet bāzes klātbūtne vairo drošỉbas sajūtu.

Pensionāre, Liepāja: Militārā zinnā viss ir kārtībāa, jo par militārajām lietām nav jādomā, primāri [par ko jādomā] tã ir sociālā un ekonomiskā drošǐba. ${ }^{29}$

Jaunietis, Liepāja: Pie mājām ir militārā šautuve, kad norisinās militārās mācības, tad aizdomājos par drošǐbu. ${ }^{30}$

Pašvaldībās, kurās nav būtiska militārā infrastruktūra (Talsi, Madona, Ļaudona, Rīga, Aizkraukle, Rēzekne, Gulbene), uzskata Krieviju par lielāku vai mazāku draudu. 
Jauniete, L,audona: Starptautiskā sistēma ir saprātīga, lìdz ar to Krievijas drauds ir maz ticams. ${ }^{31}$

Sieviete darbspējas vecumā, Talsi: Krievija kā kaimiṇi ir bīstama, taču to mēs izvèlēties nevaram. ${ }^{32}$

Jaunietis, Aizkraukle: Ja Krievija izdomātu sagraut NATO, tad Latvija būtu pir$m \bar{a}$... Krievijai nav nepieciešamas konvencionālas metodes, ar lienošu okupāciju tā varètu būt sekmīgākā. ${ }^{33}$

Savukārt Jaunjelgavas, Valmieras un Daugavpils pašvaldībās Krieviju redz kā sadarbības partneri, ar ko būtu jāīsteno kopēji attīstības projekti, kā kaimiṇu, ar kuru jāsaglabā labas attiecības. Latvija esot pārāk maza, tādēl Krievijai tā neesot vajadzīga.

Studente, Daugavpils: Latvija Krievijai nav vajadzīga, bet, ja vajadzēs, tad pañems ne tikai Latviju, bet visas Baltijas valstis. Kāpēe mums būtu jābaidās no Krievijas? Es nesaprotu, kāpēc tas mūs satrauc. Mēs esam Eiropas Savienībā, un viss. Jūs tur, Rīgā, varat no viņas baidīties, mums nav jābaidās. ${ }^{34}$

Sieviete darbspējas vecumā, Valmiera: Krievija var iejaukties, taču tai Latvija nav vajadzīga. ${ }^{35}$

Pensionāre, Jaunjelgava: Nezinu, vai būtu jāfokusējas uz Krieviju kā lielāko ienaidnieku, kā nekā kaimiņs. ${ }^{36}$

\section{Sabiedroto spēku klātbūtne}

Kopš 2004. gada, kad Latvija kḷuva par NATO dalïbvalsti, sadarbība ar sabiedrotajām valstīm kolektīvās drošibas jomā ir kḷuvusi par vienu no Latvijas aizsardzības pamatelementiem. Šì sadarbība īpaši cieša izvērtās pēc Krievijas agresijas Ukrainā, kad 2015. gadā Latvijā tika izveidota NATO spēku integrācijas vienība, kas ir pirmā NATO struktūra un komandḳēdes sastāvdaḷa. 2016. gadā NATO samitā Varšavā tika pieņemts lēmums izvietot Latvijā kaujas grupu Kanādas vadībā. Saskaṇā ar 2016. gada Valsts aizsardzības koncepciju NATO ir Latvijas drošỉbas un aizsardzības garants un ar sabiedroto spēku klātbūtni tiek nodrošināta atturēšana, turklāt "Latvijas interesēs ir panākt ilgtermiṇa risinājumu sabiedroto nozīmīgai militārajai klātbūtnei Latvijā"37.

31 Fokusa grupas intervija ar L̦audonas iedzīvotājiem 2019. gadā.

32 Fokusa grupas intervija ar Talsu iedzīvotājiem 2019. gada 2. novembrī.

33 Fokusa grupas intervija ar Aizkraukles iedzīvotājiem 2020. gada 18. janvārī.

34 Fokusa grupas intervija ar Daugavpils iedzīvotāiiem 2019. gada 27. septembrī.

35 Fokusa grupas intervija ar Valmieras iedzīvotājiem 2019. gada 23. novembrī.

36 Fokusa grupas intervija ar Jaunjelgavas iedzīvotājiem 2019. gada 19. oktobrī.

37 Saeimas paziņojums (2020). Par Valsts aizsardzības koncepcijas apstiprināšanu. Pieejams: https:// likumi.lv/ta/id/282964-par-valsts-aizsardzibas-koncepcijas-apstiprinasanu [skatīts 16.04.2020.] 
Fokusa grupu interviju izvērtējuma rezultātā var secināt, ka vairums iedzīvotāju atbalsta sabiedroto spēku klātbūtni un redz NATO kā Latvija drošības garantu. Iedzīvotāji Liepājas, Rīgas, Ādažu, Valmieras, Jaunjelgavas, Aizkraukles un Madonas pašvaldībās uzsver nepieciešamību pēc sabiedroto spēku klātbūtnes Latvijā un vērtē to kā drošìbu veicinošu faktoru.

Vīrietis darbspējas vecumā, Liepāja: Latvijas armija un NATO rada drošǐbas sajūtu, jo vecākais dēls ir karavīrs. Svarīgi, ka esam NATO un mums ir 5. pants. ${ }^{38}$ Pensionārs, Valmiera: Ja būtu vairāk sabiedroto spēku klätbūtne, bütu lielāka drošǐba, tikai vai mēs spējam uzturēt vinus. ${ }^{39}$

Vīrietis darbspējas vecumā, Rīga: Dalība NATO un ES sniedz mums priekšrocības un kalpo par atturēšanas mehānismu. NATO, cerams, varētu aizstāvēt, mēs neesam vieni paši. ${ }^{40}$

Students, Aizkraukle: Mēs esam pasargātāki, jo Latvija ir NATO. Spēku klātbūtne šeit ir pozitìva, ja nav saasinājuma, savukārt negatìvā puse ir tāda, ka abās robežas pusēs tiek pumpēti resursi. Krievi pievelk pie robežas karaspēku un atstäj, un tas nav droši. ${ }^{41}$

Apkopojot interviju rezultātus, ir iespējams arī uzzināt viedokḷus un iedzīvotāju nostāju - NATO klātbūtne tiek uztverta gan pozitīvi, gan kā drauds.

Pensionārs, Talsi: Sabiedroto spēku klātbūtne ir ilūzija, lai nomierinātu sabiedrību, un bütisks pienesums no to klätbütnes nav. ${ }^{42}$

Studente, Gulbene: Karadarbība nav prioritāri, par ko domāt, tāpēc ir ES un NATO. Tas ir bieds, ka krievi nāk. Šo izmanto, lai biedētu iedzìvotājus, un to izmanto kāds cits. ${ }^{43}$

Sieviete darbspējas vecumā, Daugavpils: Nē, viņi [sabiedroto karavīii] te staigāja $k a ̄$ saimnieki. Viṇi Daugavpilì nav vajadzīgi. ${ }^{44}$

Studente, Daugavpils: Mums ir kaut kāda mānija ar NATO. Labāk naudu iedot bērniem un veciem cilvēkiem. Priekš kam tērēt naudu NATO. Manuprāt, Latvi$j a ̄$ ir stabili. Ar to NATO nauda ir izmesta vējā. Varbüt var pieredzes apmaiņai, ik divos gados, bet pastāvīgi tas nav vajadzīgs. Latvijai nav ienaidnieku. ${ }^{45}$

Fokusa grupas intervija ar Liepājas iedzīvotājiem 2019. gada 20. augustā.

Fokusa grupas intervija ar Valmieras iedzīvotājiem 2019. gada 23. novembrī.

Fokusa grupas intervija ar Rīgas iedzīvotājiem 2019. gada 28. oktobrī.

Fokusa grupas intervija ar Aizkraukles iedzīvotājiem 2020. gada 18. janvārī.

Fokusa grupas intervija ar Talsu iedzīvotājiem 2019. gada 2. novembrī.

Fokusa grupas intervija ar Gulbenes iedzīvotājiem 2019. gada 21. septembrī.

Fokusa grupas intervija ar Daugavpils iedzīvotājiem 2019. gada 27. septembrī.

Turpat. 
Jauniete, Rēzekne: NATO drīzāk ir drauds, nevis drošības garants. Jābaidās no ASV karavīiem, jo nav zināms iemesls, kädēl tie atrodas pilsētā, nevis no Krievijas. ${ }^{46}$

\section{Nacionālie bruṇotie spēki}

Sabiedriskās domas aptaujas Latvijā rāda nemainīgu uzticību Nacionālajiem bruṇotajiem spēkiem un to veiktajām iniciatīvām drošìbas stiprināšanai. Fokusa grupas intervijās tika iegūti kvalitatīvi dati par NBS vērtējumu un noskaidrots, kā NBS attīstîba un klātbūtne spēj ietekmēt iedzīvotāju subjektīvo drošibas uztveri.

Līdzīgi kā sabiedroto spēku klātbūtni, arī Latvijas armiju vairums iedzīvotāju vērtē kā drošību veicinošu faktoru. Tā, piemēram, Liepājā, Rỉgā, Aizkrauklē, Gulbenē, Madonā un Valmierā iedzīvotāji pozitīvi vērtē gan NBS attīstību, gan arī to, ka aizsardzības budžetam ir atvēlēti $2 \%$ no valsts iekšzemes kopprodukta.

Jauniete, Gulbene: Valstī ir armija un robežsargi, tādēl par drošǐbu neuztraucos.

Turklāt Alūksnē ir bāze un Gulbenē ir robežsardze. Tagad ir žogs. ${ }^{47}$

Vīrietis darbspējas vecumā, Liepāja: Jāpilda savas saistības un $2 \%$ no budžeta ir jāmaksā, taču reāliem draudiem nacionālās spējas ir par maz. ${ }^{48}$

Pensionārs, Valmiera: Procentuāli pildām, un tas ir pilnīgi pietiekami, bet nav pārliecības par to, ko mēs varētu izdarìt pret Krievijas militāro pārspēku. ${ }^{49}$

Pensionāre, Rīga: Armija ir sakārtojusies, armijas prestižs ir audzis, un tas ir nopelns, ka par ārpolitiku tiek domāts. Liela drošǐbas sajūta, jo kā bijušajam padomju cilvēkam, kurš dzìvojis apspiestībā un stresā, ir jütamas bütiskas izmainas. ${ }^{50}$

Intervijās ir iespējams identificèt arī tās iedzīvotāju grupas, kuras uzskata, ka NBS veicina drošỉbu, bet tajā pašā laikā aizsardzībai atvēlētie 2\% ir pārāk daudz. Talsu Rēzeknes, Daugavpils un Gulbenes iedzīvotāji uzskata, ka aizsardzībai nevajadzētu tērēt vairāk, tā vietā finansējums būtu jānovirza citām jomām, piemēram, sociālajai aizsardzībai vai izglìtībai.

Pensionārs, Rēzekne: Ir laiks samazināt izdevumus apbruṇošanai. Mūsu paaudzei to nesaprast. Latvijā aizvien vairāk un vairāk ir armija. ${ }^{51}$

46 Fokusa grupas intervija ar Rēzeknes iedzīvotājiem 2019. gada 12. oktobrī.

47 Fokusa grupas intervija ar Gulbenes iedzīvotājiem 2019. gada 21. septembrī.

48 Fokusa grupas intervija ar Liepājas iedzīvotājiem 2019. gada 20. augustā.

49 Fokusa grupas intervija ar Valmieras iedzīvotājiem 2019. gada 23. novembrī.

50 Fokusa grupas intervija ar Rīgas iedzīvotājiem 2019. gada 28. oktobrī.

51 Fokusa grupas intervija ar Rēzeknes iedzīvotājiem 2019. gada 12. oktobrī. 
Vīrietis darbspējas vecumā, Daugavpils: Lìdz Gruzijai un Ukrainai tas miers bija daudz vairāk. Reāli, kad ir precedenti uz militārām intervencēm, domāšana bišķit mainās. Kad mēs noturam $2 \%$ militārām vajadzībām, bet nevaram atrast skolotājiem, pērkot vecus tankus, tad tā bilde nesaliekas nedaudz..$^{52}$

Students, Talsi: Satrauc, ka liela daḷa budžeta aiziet aizsardzībai un iepērk vecu tehniku. ${ }^{53}$

Fokusa grupas intervijās varēja arī uzzināt, ka Talsu, Ādažu, Jaunjelgavas, Rēzeknes un Daugavpils iedzīvotāji jūtas nedroši tieši NBS klātesamības dēl vai arī uzskata, ka iztērētajam aizsardzības finansējumam militārajām spējām vajadzēja būt jēgpilnākam.

Sieviete darbspējas vecumā, Daugavpils: Militäro budžetu plānojot, tajā jāparedz arī investīijas reǵiona iedzīvotājos vai, piemēram, reǵgiona.$^{54}$

Vīrietis darbspējas vecumā, Jaunjelgava: Izskatās, ka nauda tiek tèrēta neadekvāti, un to nevajadzētu uztvert kā pašmērkịi. Brīžiem izskatās, ka tiek plānots, ko vēl var nopirkt. Jāsaved kārtībā to mazumiņu, lai nauda aiziet reğioniem, piemēram, ZS. Helikopteru pirkšana nav adekvāta..$^{55}$

Sieviete darbspējas vecumā, Talsi: Man kā sievietei drošǐbu nerada, jo dabūsim pirmo triecienu, kur atrodas militārās bāzes. ${ }^{56}$

No fokusa grupas intervijās iegūtajiem kvalitatīvajiem datiem var secināt, ka iedzīvotāji atbalsta NBS klātbūtni, bet atsevišķos gadỉjumos militārās infrastruktūras tuvums rada viņos diskomfortu, tāpēc viṇi NBS klātbūtni uztver negatīvi. Apdraudējums izriet no uzskata, ka potenciāla kara gadījumā militārā infrastruktūra tiktu iznīcināta vispirms un tā, kura atrodas apdzīvotu vietu tuvumā, tiešã veidā ietekmētu iedzīvotājus. Taču tajā pašā laikā tā veicina apdzīvoto vietu ekonomisko izaugsmi, kas mazina apdraudējuma negatīvo uztveri, kā to pierāda arī Ādažu gadījums. Līdz ar to subjektīvajā drošỉbas uztverē militārās infrastruktūras klātbūtne ir drauds, bet tās sniegtais ekonomiskais ieguvums mīkstina draudu uztveri.

Runājot par visaptverošas valsts aizsardzības sistēmu, iedzīvotāji visās pašvaldībās, kurās tika veiktas fokusa grupu intervijas, uzsvēra, ka šĩ sistēma līdz galam nav skaidra vai arī trūkst būtiskas informācijas par to, kā plānots šo sistēmu ieviest un kas būtu jādara iedzìvotājiem.

\footnotetext{
52 Fokusa grupas intervija ar Daugavpils iedzīvotājiem 2019. gada 27. septembrī.

53 Fokusa grupas intervija ar Talsu iedzīvotājiem 2019. gada 2. novembrī.

54 Fokusa grupas intervija ar Daugavpils iedzīvotājiem 2019. gada 27. septembrī.

55 Fokusa grupas intervija ar Jaunjelgavas iedzīvotājiem 2019. gada 19. oktobrī.

56 Fokusa grupas intervija ar Talsu iedzīvotājiem 2019. gada 2. novembrī.
} 
Vīrietis darbspējas vecumā, Liepāja: Mēs kā sabiedrība neesam gatava mazākām krīzèm, vai mēs būtu gatavi kaut kam lielākam? Šeit ir l̦oti daudz darāmā, turklāt jaunai paaudzei nav sajēgas, ko un kā darīt. ${ }^{57}$

Vīrietis darbspējas vecumā, Jaunjelgava: Cilvēki sāk nogurt no drošības saistīšanas ar armiju. Vajag attīstìt skautismu. ${ }^{58}$

Sieviete bezdarbniece, Valmiera: Visaptverošas valsts aizsardzības iniciatīva ir atbalstāma. Jautājums, kā to stāsta, jo ne visi būs šāvēji. Lìdz ar to pirmā medicìniskā palìdzìba obligāti būtu ieviešama skolā. Vajag cilvēkiem šo iniciatìvu izskaidrot vairāk. ${ }^{59}$

Vīrietis darbspējas vecumā, Rīga: Trūkst informācijas, ko darīt, iet uz tuvāko Zemessardzes punktu vai armijas daḷu. Krimas scenārijs varētu būt reāls Daugavpilī vai Rīgā dēl krievvalodīgajiem, viegli būtu iefiltrēt citus elementus. Mums pašiem arī kaut kas jādara, lai vienkārši nepārietu pāri. ${ }^{60}$

Interviju laikā iegūtās informācijas analīze liek secināt, ka iedzīvotāju informētības līmenis par visaptverošu valsts aizsardzību ir samērā zems. Pamatā tiek norādīts, ka trūkst informācijas par civilās aizsardzības plāniem, par kuriem tieši atbild Iekšlietu ministrija, bet pastarpināti - Aizsardzības ministrija. Taču saskaṇā ar 2019. gada 8. janvārī valdības apstiprināto Aizsardzības ministrijas informatīvo ziņojumu "Par visaptverošas valsts aizsardzības sistēmas ieviešanu Latvijā" ${ }^{61}$ civilā aizsardzība tiek definēta kā viena no jomām, kuru būtu nepieciešams pilnveidot, lai attīstītu visaptverošas valsts aizsardzības konceptu. Turklāt jebkurš militārais konflikts ietekmē sabiedrību un tās aizsardzības plānus, tādējādi padarot Aizsardzības ministriju par līdzatbildīgu sabiedrības izglītošanā.

Kopumā visās pašvaldībās, kurās tika veiktas fokusa grupas intervijas, tika pausts atbalsts valsts visaptverošas aizsardzības sistēmai, jo tā ietvertu norādījumus par iedzīvotāju uzdevumiem atkarībā no viṇu spējām, zināšanām un profesijas un par viṇu rīcību krīzes situācijā, dabas katastrofā vai militāra apdraudējuma gadījumā. Atsevišḳās pašvaldībās (piemēram, Valmierā) iedzīvotāji uzskatīja, ka nepieciešams informatīvs izdevums (kā Lietuvā vai Zviedrijā), kur īsumā būtu aprakstīta jebkura vispārēja rīcība krīzes situācijā.

57 Fokusa grupas intervija ar Liepājas iedzīvotājiem 2019. gada 20. augustā.

58 Fokusa grupas intervija ar Jaunjelgavas iedzīvotājiem 2019. gada 19. oktobrī.

59 Fokusa grupas intervija ar Valmieras iedzīvotājiem 2019. gada 23. novembrī.

60 Fokusa grupas intervija ar Rīgas iedzīvotājiem 2019. gada 28. oktobrī.

61 Ministru kabinets (08.01.2019.). Informatīvais ziņojums "Par visaptverošas valsts aizsardzības sistēmas ieviešanu Latvijä”, 2. lpp. Pieejams: http://tap.mk.gov.lv/mk/tap/?pid=40462120 


\section{Militārā drošība pašvaldībās}

Šajā apakšnodaļā ir analizēti militārās drošỉbas sektora pārvaldības rādītāji tajās Latvijas pašvaldībās, kur militārie draudi tika uzskatīit par prioritāriem. Tā kā tikai Ādažu iedzīvotāju skatījumā militārie draudi ir visbūtiskākie, tad šajā apakšnodạ̦ā papildus ir apskatītas arī citas pašvaldības (Jaunjelgava, Rēzekne un Liepāja), kurās militārie draudi netika uzskatīti par prioritāriem draudiem. Tika analizēts pašvaldības darbinieku viedoklis par drošības jautājumiem, kā arī pètījumā iesaistīto pašvaldību civilās aizsardzības plāni. ${ }^{62}$

\section{Ādažu novada pašvaldība}

Intervijā ar Ādažu pašvaldības darbinieku militārā sektora draudi tika uzskatīti par būtiskiem tieši militāāās infrastruktūras dēḷ.

Bāze pievilina gan huligānus, gan reālus Krievijas aǵentus, gan kaut ko pa vidudronu lidinātājus virs bāzes utt. ${ }^{63}$

N̦emot vērā tuvumā esošo militāro infrastruktūru, pašvaldība saredz komunikācijas problēmas gan ar Aizsardzības ministriju meža ugunsgrēku gadījumā, kurš izcel̦as militārās aktivitātes poligonā, gan ar vietējiem iedzīvotājiem, informējot viņus par iespējamo rīcību krīzes situācijā. Iedzīvotāju informētîbai par pakalpojumu pieejamību krīzes situācijā pašvaldība plāno izmantot "Ādažu Vēstis", taču šobrīd tas netiek darīts, lai gan pēc Ukrainas krīzes ticis praktizēts.

Iepriekš, kad izpilddirektors bija zemessargs, tas ticis isstenots tūlìt pēc 2014. gada notikumiem Ukraina..$^{64}$

Civilās aizsardzības scenāriju praktizēšana tiek uzskatīta par nepieciešamu, jo pašvaldības darbinieku civilās aizsardzības atkārtotās apmācībās tiktu simulēta krīzes situācija un trenēta lēmumu pien̦emšana.

Civilās aizsardzības sistēmas mācības ir bijušas dānu ekspertu vadībā. ${ }^{65}$

62 Saskaṇā ar Valsts ugunsdzēsības un glābšanas dienesta mājaslapā pieejamo informāciju civilā aizsardzība ir pasākumu kopums, kurus īsteno valsts un pašvaldību institūcijas un sabiedrība, lai nodrošinātu cilvēku, vides un īpašuma drošību, kā arī īstenotu atbilstošu rīcību katastrofas un katastrofas draudu gadījumā. Viens no civilās aizsardzības uzdevumiem ir saistīts arī ar militāro drošỉbu, proti, nodrošināt atbalstu valsts aizsardzības sistēmai, ja noticis militārs iebrukums vai sācies karš. VUGD. Civilā aizsardzība. Pieejams: https://vugd.gov.lv/lat/par_vugd/darbibas_sferas/ civila_aizsardziba [skatīts 06.09.2020.]

63 Padziḷinātās intervijas ar Ādažu novada pašvaldības darbinieku 2020. gada 13. janvārī.

64 Turpat.

65 Turpat. 
Apskatot Ādažu civilās aizsardzības plānu, var secināt, ka pašvaldība ir ņēmusi vērā militārās infrastruktūras klātesamību, uzsverot, ka tās teritorijā ir izvietota viena no lielākajām militārajām bāzēm Baltijas valstīs. Kā tiek norādìts plānā, tās klātesamība tiek saistīta ar meža ugunsgrēka bīstamību tieši militārā poligona dệ̣. ${ }^{66}$ Tāpat plānā tiek runāts par bruṇotu konfliktu vai militāru iebrukumu.

Bruñots konflikts var izraisìties pierobežā vai iekšzemē. Tajā var tikt iesaistìtas bruņotas grupas, lai izraisītu konfliktsituāciju starp valstīm vai vienas valsts iekšienē, kas skar valsts teritoriju vai tās valdību. ${ }^{67}$

Civilās aizsardzības plānā nav detalizēti norādīts, kāda būtu pašvaldības rīcība militārās krīzes situācijās, vien uzsvērts, ka tā izṇēmuma ${ }^{68}$ vai mobilizācijas gadījumā apziņotu mobilizējamās personas, valsts institūciju darbiniekus un iedzīvotājus. ${ }^{69}$ Militāras krīzes situācijā pašvaldības rīcība tiktu noteikta ar atsevišķiem Ministru kabineta rīkojumiem.

Saskaņā ar Ministru kabineta noteikumiem par civilās aizsardzības plānu struktūru un tajos iekḷaujamo informāciju Ādažu pašvaldības civilās aizsardzības plānā nav aprakstìta pašvaldības rīcība militāra iebrukuma vai kara gadijjumā. ${ }^{70}$ Saskaņā ar pētijuma laikā izveidoto labas pārvaldības matricu, kur normatīvo aktu izmaiṇas ir viens no labas pārvaldības kritērijiem, Ādažu pašvaldība neizpilda kritēriju par esošo plānu aktualizāciju vai jaunu izstrādi, jo pēdējais apstiprinātais civilās aizsardzības plāns ir ticis aktualizēts vien 2013. gadā.

\section{Jaunjelgavas novada pašvaldība}

Jaunjelgavas pašvaldība analīzei tika izvēlēta tāpēc, ka šajā pētījumā iedzīvotāju ziṇā tā ir viena no mazākajām pašvaldībām, turklāt tās iedzīvotāju subjektīvajai drošîbas uztverei raksturīgs tas, ka viṇi ārējo apdraudējumu nesaskatīja.

66 Ādažu pašvaldība (2013). Civilās aizsardzības plāns. Pieejams: https://www.adazi.lv/pasvaldiba/ dokumenti/civilas-aizsardzibas-plans/ [skatīts 07.09.2020.]

67 Turpat, 32. lpp.

68 Saskaṇā ar likumu “Par Ārkārtas situāciju un izṇēmuma stāvokli” izṇēmuma stāvoklis ir īpašs tiesiskais režīms, kas izsludināms, ja valsti apdraud ārējais ienaidnieks vai valstī vai tās daḷā ir izcēlušies vai draud izcelties iekšējie nemieri, kas apdraud demokrātisko iekārtu. Skatīt: Saeima (2013). Par ārkārtējo situāciju un izṇēmuma stāvokli. Pieejams: https://likumi.lv/ta/id/255713-par-arkartejo-situaciju-un-iznemuma-stavokli [skatīts 07.09.2020.]

69 Ādažu pašvaldība (2013). Civilās aizsardzības plāns, 39. lpp. Pieejams: https://www.adazi.lv/pasvaldiba/dokumenti/civilas-aizsardzibas-plans/ [skatīts 07.09.2020.]

70 Ministru kabineta noteikumi Nr. 658 "Noteikumi par civilās aizsardzības plānu struktūru un tajos ieklıujamo informāciju”. Pieejams: https://likumi.lv/ta/id/294938-noteikumi-par-civilas-aizsardzibasplanu-strukturu-un-tajos-ieklaujamo-informaciju [skatits 07.09.2020.] 
Turpretim pašvaldības darbinieks domā, ka no ārējā apdraudējuma viedokḷa būtiskākos draudus rada Krievija, jo:

Jāapzinās starptautiskās drošības situācija, kur savu lomu vēsturiski spēlē agresīvās Krievijas faktors. ${ }^{71}$

No drošības viedokḷa tiek akcentēta zemessargu loma, taču, tā kā Aizkraukles bataljona struktūras ir mainīta, tiek norādīts, ka arī to aktivitāte pašvaldībā ir samazinājusies.

[Zemessargi] piedalās svinīgos pasākumos, ir jaunsargi, bet reti kad kaut kas [militāras mācības] notiek. ${ }^{72}$

Pašvaldības darbiniekam nav skaidrs, kā būtu jārīkojas krīzes situācijā. Tā, piemēram, pārskatot Jaunjelgavas mājaslapu, tajā neizdevās atrast apstiprinātu civilās aizsardzības plānu, kas saskaņā ar Civilās aizsardzības un katastrofas pārvaldīšanas likumu ir viens no pašvaldības domes uzdevumiem. ${ }^{73}$ Lìdz ar to arī šajā pašvaldībā, izmantojot labās pārvaldības matricu, nav iespējams konstatēt normatīvo aktu (pašvaldības gadījumā - saistošo noteikumu) izmaiṇas, nemaz jau nerunājot par to izstrādi rīcībai ārkārtas gadījumos. Runājot par pašvaldības rīcību krīzes situācijā, tika norādīts:

Pašvaldība pati nezina, kā rīkotos. Ja iedzīvotājiem trūkst informācijas, tad tā ir pašu vaina, jo cilvēki paši neinteresējas. Pēc Ukrainas 2014. gadā uzdevu šo jautājumu Pašvaldības savienībai, kā arī Zemessardzes bataljoni organizēja mācības, $k \bar{a}$ rìkoties. Nav speciālu instrukciju, kā rīkoties ärējas agresijas gadījumāa Nav skaidrs, iespējams, valdība pieņems kädus likumus. Pastāv divas iespējas - vai visu iznīcināt, vai saglabāt un nodrošināt visu nepieciešamo - ūdens, apkure utt. Jautājums, kas notiek ar vietējo varu? Gaida ienākošo karaspēku vai pamet šo teritoriju, cilvēkiem nav skaidrs. ${ }^{74}$

\section{Liepājas valstspilsētas pašvaldība}

Liepājas pašvaldība analīzei tika izvēlēta tāpēc, ka, līdzīgi kā Ādažos, arī šīs pašvaldības teritorijā ir izvietota NBS Jūras spēku militārā infrastruktūra. Intervijā ar Liepājas pilsētas pašvaldības darbinieku uzzinām, ka arī šeit pastāv

Padziḷinātās intervijas ar Jaunjelgavas pašvaldības darbinieku 2020. gada 31. janvārī

Turpat.

73 Saeima (2016). Civilās aizsardzības un katastrofu pārvaldīšanas likums, 11. pants. Pieejams: https://likumi.lv/ta/id/282333-civilas-aizsardzibas-un-katastrofas-parvaldisanas-likums [skatīts 07.09.2020.]

74 Padzị̣inātās intervijas ar Jaunjelgavas pašvaldības darbinieku 2020. gada 31. janvārī. 
potenciāli Krievijas draudi. Taču militāro vienību un sabiedroto spēku klātesamība Latvijā vairo drošǐbu.

Liepāja šajā zinnā ir jūtīga vieta, jo jānnem vērā, ka Krievijas vēstniecībai Latvijā ir divi ǵenerālkonsulāti - Daugavpilī un Liepājā. Tas nozīmēe, ka kaimiņi Krievijā redz savu interešu zonu arī Liepājāa. Tas mums jāatceras, un to nevar par zemu novērtēt. Tädēl es nekad neuzdrošinātos spēelèties ar drošības jautäjumiem, kā to darīja mani kolēgi Ventspilī. NATO klātbūtne ievieš drošību. Jāatceras, ka Liepāja vienmēr ir bijusi stratēgisks objekts un mès esam kaimiņu [Krievijas] interešu lok $\bar{a}^{75}$

Pašvaldības darbinieka ieskatā, ņemot vērā vēsturisko pieredzi - notikumus, kas norisinājās Liepājā 90. gados, kad Zemessardze spēja ieviest kārtību, arī mūsdienās zemessargi ir tie, kuri veicina drošỉbu reǵionā.

Man prieks, ka zemessargiem tieši Liepāja ir epicentrs, kas pārklāj visu Kurzemi. Zemessargi lielā mērā dod drošību liepājniekiem un visiem kurzemniekiem, jo, redzot militāro klātbūtni, mazinās nedrošība, ko rada Krievijas aktivitāšu klātbütne. Ja nav šo acìmredzamo struktüru, kuras mūs varētu aizsargāt, tad ir liela nedrošìba, bet ir klät spēki, kuri ir auguši profesionālās prasmēs, apgādē un zināšanās, tad palaušanās pieaug. ${ }^{76}$

Liepājas pašvaldības darbinieks uzskata, ka Liepāja ir stratēgiski svarīga pilsētu un ka militārā drošîba ir viens no tās aktuālajiem jautājumiem, tāpēc ir būtiski analizēt Liepājas civilās aizsardzības plānu, lai noskaidrotu pašvaldības rīcības algoritmus, kā pašvaldība rīkotos militāra apdraudējuma gadījumā. Līdzšinējo civilās aizsardzības plānu Liepājas pilsētas dome ir apstiprinājusi 2013. gadā, bet atjaunojusi 2019. gada 25. aprīlī. Pārskatot šo plānu, jāsecina, ka tas neietver ārējos normatīvajos aktos noteikto rīcības aprakstu par civilās aizsardzības sistēmas darbību militāra iebrukuma vai kara gadījumā. Līdz ar to no labas pārvaldības viedokḷa Liepājas pašvaldība nav ievērojusi valsts normatīvos aktus un nav veikusi labojumus pilsētas saistošajos noteikumos, papildinot civilās aizsardzības plānu ar rīcības aprakstu.

\section{Rēzeknes novada pašvaldība}

Fokusa grupas intervijās Rēzeknes pašvaldības iedzīvotāji nenorādīja, ka viens no galvenajiem apdraudējumiem ir militārās drošības draudi, un uzskatīja, ka NBS, sabiedroto bruṇotie spēki un NATO neveicina drošību un ka aizsardzībai 
nebūtu jāatvēl 2\% no IKP. Šì iemesla dēḷ Rēzeknes pašvaldība no visām projektā iesaistītajām pašvaldībām tika izvēlēta, lai noskaidrotu, vai iedzīvotājiem aktuālie draudi ir attiecināmi arī uz pašvaldību.

Analizējot datus, kas iegūti intervijā ar Rēzeknes pašvaldības darbinieku, var secināt, ka Krievija tiek uztverta kā apdraudējums, bet tiek uzsvērts, ka iedzīvotājiem ir arī otrs viedoklis - Krievija nav drauds.

Manuprāt, jā, ir, protams, viedokḷi. Ir cilvēki, kuri uzskata, ka tas [Krievijas tuvums] var apdraudēt vinun personīgo drošību. Sāksies tā rezultātā kāds konflikts. Vairāk es domāju, ka tādus viedokḷus iespaido tas, ko mès lasām presē, skatāmies TV, jo tiešā saskarsmē vai personīgas pieredzes nav cilvēkiem šajā saistībā. ${ }^{77}$

Runājot par Nacionālajiem bruṇotajiem spēkiem, pašvaldības darbinieks uzsver, ka to klātbūtne palielina drošību, jo tiek attīstīta militārā infrastruktūra. Turklāt vietējo iedzīvotāju iesaiste vai nu Zemessardzē, vai arī NBS profesionālajā dienestā tikai vairo drošỉbu. Bet tiek paustas arī bažas par to, ka drošỉba var tikt ietekmēta, ja karavīrs neizskatās atbilstoši, ar to domājot neatbilstošu ekipējumu vai apgēerbu.

Praktiski uz ielas ir tie paši vietējie iedzīvotāji, virsnieki, un tāpēc mēs vinuus nevaram uztvert kā draudu. Vairāk tas var dot lielāku drošǐbu, jo, ja kaut kas notiks, tad mès esam aizsargāti. Bet, protams, tā drošìbas sajūta var büt apdraudēta, ja karavīri neizskatās, pēc cilvēku uzskatiem, atbilstoši, piemēram, ir korpulents nu kā viņš var aizstāvēt, vai neatbilstoši géerrbies cilvēks, mētelis militārais, bet bikses citas. ${ }^{78}$

Arī aizsardzībai atvēlētos $2 \%$ no IKP pašvaldības darbinieks vērtē pozitīvi, uzsverot to, ka norisinās acīmredzama attīstība, kas vairo militāro drošību un veicina kopējo drošîbu pilsētā.

Tas, ko es personīgi redzu, - vieta, kura atvēlēta militärajai vienībai, un tur nemitīgi notiek darbi - vini sakārto savas teritorijas. Manī tas palielina drošības sajūtu. Es redzu, ka tur ir investīicijas un tās investīiijas ir pareizas. Tas palīdz arī sakārtot pilsētas vidi, un tās arī dod lielāku drošības sajūtu. ${ }^{79}$

Rēzeknes iedzìvotāju un Rēzeknes pašvaldības darbinieku viedokḷli ir atšķirīgi. Pašvaldībā NBS, sabiedroto spēku klātbūtne un aizsardzības finansējums tiek vērtēts kā drošību veicinošs faktors, savukārt iedzīvotājiem tas šķiet

\footnotetext{
77 Padziḷinātās intervijas ar Rēzeknes pašvaldības darbinieku 2020. gadā.

78 Turpat.

79 Turpat.
} 
kā apdraudējums. Izmantojot labas pārvaldības matricu, tika skatīts arī Rēzeknes pašvaldības sagatavotais civilās aizsardzības plāns, lai noskaidrotu tās rīcību potenciāla militāra iebrukumu gadījumā. Apvienotais Rēzeknes un Vị̣ānu novadu civilās aizsardzības plāns neparedz šo pašvaldību rīcỉbu militāra iebrukuma gadījumā. Plānā ir iekḷauts jautājums par mobilizējamiem resursiem, kas varētu tikt attiecināti uz militāru krīzi, bet tas plašāk netiek izvērsts, vien norādot, ka Rēzeknes un Viḷānu novadā nav izveidoti mobilizējamie civilās aizsardzības formējumi. ${ }^{80}$

Analizējot iegūtos datus par pašvaldībām, var secināt, ka pašvaldību darbiniekiem ārējais apdraudējumus ir viens no faktoriem, kas ietekmē subjektīvo drošības uztveri. Iegūtos datus salīdzinot ar iedzīvotāju draudu uztveri, secināms, ka ārējā apdraudējuma uztvere šajās pašvaldībās ir līdzvērtīga, izṇemot Rēzekni, kur iedzīvotājiem nebija viennozīmīgs viedoklis par Krieviju kā ārējo draudu.

Līdzīgi ir ar sabiedroto spēku klātbūtni, kas tiek uztverta kā drošību veicinošs faktors. Taču NBS klātesamība un ar to saistītie drošības aspekti ir atšķirīgi, to īpaši akcentē Ādažu pašvaldība, savukārt citās pašvaldībās NBS klātbūtne rada drošîu.

Tā kā no labas pārvaldības matricas militārā sektora analīzei tika izmantots tikai normatīvo aktu izmaiņu rādītājs, ar kura palīdzību tika mērìtas izmaiṇas pašvaldību civilās aizsardzības plānā, tad visaptverošus secinājums izdarīt nav iespējams. Taču var iezīmēt kopēju tendenci militārās drošỉbas sektorā, piemēram, pašvaldības reti pārskata un aktualizē civilās aizsardzības plānus, tajos nav iekḷautas ārējos normatīvajos aktos noteiktās izmaiṇas, kas attiecas uz pašvaldības rīcību militāra apdraudējuma gadījumā.

Tikai Ādažu pašvaldība ir nedaudz iezīmējusi tās rīcību militārās krīzes gadījumā, bet arī vien tādēḷ, ka novadā atrodas lielākais militārais poligons Baltijas valstīs. Jaunjelgavas pašvaldībā vispār nav pieejams civilās aizsardzības plāns un pašvaldības darbiniekiem nav informācijas, kā rīkoties. Lai gan Liepājai un Rēzeknei ir šādi plāni, tie nenosaka pašvaldības rīcību militāras krīzes situācijā. Pamatojoties uz iegūtajiem datiem, jāsecina, ka pašvaldības nav pievērsušas īpašu vērību militārās drošības sektora apdraudējuma mazināšanai.

80 Viḷānu novads (2018). Rēzeknes novada un Viḷānu novada pašvaldību civilās aizsardzības plāns, 24. lpp. Pieejams: https://www.vilanunovads.lv/lv/civilas-aizsardzibas-plans/ [skatīts 08.09.2020.] 


\section{Secinājumi}

Fokusa grupu interviju laika posmā (2019. gada rudens/ziema) militārais sektors iedzīvotājiem neškịiet aktuāls, prioritāri viņiem šķiet veselības, sociālās labklājỉbas un ekonomikas sektora draudi. Militārie draudi iedzīvotāju drošības uztverē nav tik nozīmīgi kā tie, kuri skar pamatvajadzību nodrošināšanu. Vienīgi retais aptaujātais kā galveno draudu uzsver militāro apdraudējumu sev un gimenei.

Pētijumu centra SKDS veiktajās aptaujās kā nozīmīgāko draudu iedzīvotāji minējuši ekonomisko un personīgo apdraudējumu (noziedzību), bet militārais drauds tika nosaukts kā trešais nozīmīgākais draudu veids. ${ }^{81}$ Arī šajā pētījumā militārie draudi iedzīvotājiem nav aktuāli un par tiem ikdienā netiek domāts. Šādai situācijai var būt vairāki iemesli, ko atzīst arī paši iedzīvotāji, ka valsts ìsteno sekmīgu aizsardzības politiku un iedzīvotājiem par militārās drošības jautājumiem nav jāsatraucas, tādējādi subjektīvajā drošỉbas uztverē prevalē nemilitāra rakstura draudi. Lai gan vairākos nacionāla līmeṇa un starptautiskos analīzes dokumentos tiek norādīts, ka Baltijas valstu, tātad arī Latvijas drošību apdraud Krievija, tomēr iedzīvotāju vairumam tas nav iemesls subjektīvās drošības uztveres maiņai, ja vien draudi nav izteikti reāli.

Interesants škita fakts par draudu atšķirīgo uztveri, salīdzinot Ādažu un Liepājas fokusa grupu interviju rezultātus. Lai gan abās pašvaldībās ir izvietota ievērojama militāra infrastruktūra, tomēr tās dēḷ izteiktāku militāro apdraudējumu izjūt Ādažu iedzīvotāji. Tas skaidrojams ar militāās infrastruktūras intensīvāku izmantošanu, piemēram, Ādažos ir izvietota NATO paplašinātās klātbūtnes kaujas grupa un atrodas lielākais militārais poligons Baltijā. Tur uz mācībām ik gadus ierodas sabiedroto valstu bruņotie spēki. Savukārt Liepājāa sabiedroto spēku klātbūtne nav tik intensīva, turklāt Jūras spēku apmācības notiek galvenokārt jūrā, tāpēc militāro aktivitāšu radītās sekas (troksnis, karavīru klātbūtne ielās) iedzīvotāji ikdienā neizjūt.

Pētijuma gaitā iezīmējās atšķirīga subjektīvā draudu uztvere Daugavpilī un Rēzeknē, kur par galveno draudu tiek uzskatīta sabiedroto spēku klātbūtne. Tajā pašā laikā iedzīvotāju subjektīvajā drošības uztverē NATO un ES tiek skatīts kā drošības garants, ìpaši izceḷot tieši ES nozīmi. To varētu skaidrot ar ES finanšu instrumentu investīcijām pašvaldību infrastruktūras objektos, kas iedzīvotājos rada pārliecību par sava veida drošību. Kā intervijā uzsver

81 SKDS (2016. gada novembris). Latvijas iedzīvotāju viedoklis par valsts aizsardzības jautājumiem: Latvijas iedzīvotāju aptauja. Pieejams: https://www.mod.gov.lv/sites/mod/files/document/SKDS_ aptauja_2016\%20\%281\%29.pdf [skatīts 07.04.2020.] 
Rēzeknes pašvaldības darbinieks, personīgo drošǐbu rada fakts, ka ir redzama, piemēram, militārās infrastruktūras attīstîba reg̣ionā vai notiek kāda cita rīcība, kas veicinātu vietējo iedzīvotāju atbalstu NATO. Lai mazinātu iedzīvotāju uztraukumu par NATO kā draudu, ìpaši svarīga ir ne tikai komunikācija ar sabiedrību šajās pašvaldībās, bet arī redzamāka NBS klātbūtne militāro mācību, publisko pasākumu laikā vai īstenojot citas sadarbības programmas, kā tas ir Ādažu pašvaldībā. ${ }^{82}$ Būtiski ir uzsvērt, ka tieši šajās pašvaldībās ir nepieciešama aktīvāka rīcība. Svarīga ir šo pasākumu intensitāte, lai sabiedrība pierastu, ka ne tikai NBS, bet arī sabiedrotie sniedz drošǐbu.

Salīdzinot iedzīvotāju draudu uztveres rādītājus ar pašvaldību darbinieku viedokḷiem, var secināt, ka iegūtais rezultāts ir visnotaḷ atšķirīgs. Spilgtākais piemērs ir Jaunjelgava, kur iedzivotājus neuztrauc ārējais apdraudējums, kamēr pašvaldības darbinieks uzskata Krieviju par ārējo apdraudējumu. Arī savstarpējā komunikācija Jaunjelgavā ir sarežğìta, jo iedzīvotājus uztrauc tas, ka pašvaldība nekomunicē ar viniem par to, kā būtu jārīkojas krīzes situācijā. Pašvaldība norāda, ka tā ir pašu iedzīvotāju vaina, ka viṇi neinteresējas, kas būtu darāms šādās situācijās. Arī pati pašvaldība nezina, kā būtu jārīkojas, jo nav civilās aizsardzības plāna, uz kura pamata būtu izstrādāti iedzīvotāju apziņošanas algoritmi.

Pētijumā gaitā tika noskaidrots, ka vairumā apskatīto pašvaldỉbu civilās aizsardzības plāni nav aktualizēti un tajos nav aprakstīta pašvaldību rīcība militārās agresijas gadījumā. Lai gan ārējie normatīvie akti nosaka šādu sadaḷu iekḷaušanu katras pašvaldības plānā, civilās aizsardzības plāni joprojām pamatā balstās uz dabas katastrofu un tehnogēno katastrofu pārvarēšanas algoritmiem. Caurskatot plānus, nākas secināt, ka militāras krīzes gadījumā pašvaldïbas paḷautos uz valdỉbas pien̦emtajiem lēmumiem, tādējādi, iespējams, apgrūtinot krīzes radīto seku pārvarēšanu, nevis ar saviem izstrādātajiem algoritmiem veicinātu iedzīvotāju drošību un ātrāk neitralizētu krīzes sekas.

Tika arī noskaidrots, ka ar valsts aizsardzību saistītie dokumenti atspoguḷo iedzīvotāju bažas par ārējo apdraudējumu. Tā, piemēram, Krievija kā viena no būtiskākajiem ārējiem draudiem tiek minēta Valsts aizsardzības koncepcijā, kas apstiprināta 2020. gada 24. septembrī. Koncepcija ir viens no pamatdokumentiem, kurā tiek iezīmēti galvenie draudi un turpmākā rīcība šo draudu mazināšanai četru gadu periodā. Atšḳirīibā no iedzīvotājiem, kas atsevišķās pašvaldībās min tādus draudus kā NBS militārās infrastruktūras klātesamība, sabiedroto spēku vai NATO klātbūtne, Valsts aizsardzības

82 Ādažos tiek minēts, ka sadarbība ar armiju izpaužas kā, piemēram, žoga uzlikšana vai kā Kanādas karavīru dāvinājums - ponijs - "Dzīvo sapṇu dārzam". 
koncepcija uzsver pretējo - Latvijas aizsardzība ir balstīta kolektīvās drošības sistēmā, kas izpaužas caur sabiedroto spēku klātbūtni un NBS militāro spēju attīstību. ${ }^{83}$ Tajā pašā laikā šajā koncepcijā tiek uzsvērts, ka būtiskākie draudi ir NATO valstu nepietiekamais finansējums, teroristiskie grupējumi, klimata pārmaiņas, tehnologiju attīstība u. c. ${ }^{84}$

83 Skatīt: Aizsardzības ministrija (2020). Valsts aizsardzības koncepcija, 3-27. lpp. Pieejams: AiMVAK_2020.pdf (mod.gov.lv) [skatīts 14.09.2020.]

84 Turpat, 5.-6. lpp. 